\title{
Infection dynamics of a $V$. splendidus strain pathogenic to Mytilus edulis : In vivo and in vitro interactions with hemocytes
}

\author{
Ben Cheikh Yosra ${ }^{1,{ }^{*}}$, Travers Marie-Agnes ${ }^{2}$, Le Foll Frank ${ }^{1}$ \\ ${ }^{1}$ Univ Le Havre Normandie, FR CNRS Scale 3730, Environm Stresses \& Aquat Biomonitoring, UMR I \\ INERIS URCA ULH SEBIO 02, F-76063 Le Havre, France. \\ 2 IFREMER, SG2M, LGPMM, Ave Mus de Loup, F-17390 La Tremblade, France. \\ *Corresponding author : Yosra Ben Cheikh, email address : yosra bencheikh@yahoo.fr
}

\begin{abstract}
:
The pathogenic strain $V$. splendidus 10/068 1T1 has previously been reported for its virulence to the blue mussel and for its capacity to alter immune responses. In this study, we expanded the knowledge on hemocyte-pathogen interactions by using in vitro and in vivo assays. V. splendidus 10/068 1T1 severely inhibited cell adhesion and acidic vacuole formation unlike the innocuous phylogenetically related $V$. splendidus 12/056 M24T1 which had no effect on these cell functions. Furthermore, the virulent bacteria decreased hemocyte viability (59\% of viability after $24 \mathrm{~h}$ ). Infection dynamics were explored by using a model based on water tank cohabitation with septic mussels infected by GFP. tagged V. splendidus 10/068 1T1. Experimental infections were successfully produced $(16.6 \%$ and $45 \%$ mortalities in 3 days and 6 days). The amount of GFP Vibrio in seawater decreased during the experiment suggesting its horizontal transfer from diseased animals to healthy ones. At the same time periods, bacteria were detected in hemocytes and in various organs and caused necrosis especially in gills. Total hemocyte count and viability were affected. Taken together, our results indicate that the pathogen $V$. splendidus 10/068 1T1 colonizes its host both by bypassing external defense barriers and impairing hemocyte defense activities.
\end{abstract}

\section{Highlights}

- Establishment of mussel experimental infection by V. splendidus via cohabitation. Detection of the GFP- $V$. splendidus strain in mussel tissues and hemocytes. Necrosis of gills during experimental infection by the virulent Vibrio strain. The virulent strain alter phagolysosome maturation, hemocyte adhesion and viability.

Keywords : Innate immunity, Bivalves, Vibrio, Infection, Experimental model, Hemocyte 


\section{Introduction}

Heterotrophic bacteria belonging to the genus Vibrio are highly abundant in the aquatic environment, mostly in seawater [1]. These ubiquitous microorganisms persist in a variety of geographic areas in interaction with eukaryotic marine hosts including zooplankton, sponges, corals and molluscs [1]. Vibrio sp. show a remarkable biodiversity. Until now, more than 110 species of Vibrios have been identified, displaying a variety of host association modalities that extend from symbiosis to virulent pathogenicity [2,3].

Many species of pathogenic Vibrios are known to be responsible for diseases in terrestrial or marine vertebrates and invertebrates. Vibrio cholerae, Vibrio vulnificus and Vibrio parahaemolyticus in particular cause severe disorders in humans [4,5]. In numerous aquatic organisms including fish [6], corals [7], shrimp [8] and shellfish [9], some Vibrios have been associated with serious infections. Because of the high economic loss generated in the aquaculture sector, many studies are dedicated to bacterial diseases, particularly in farmed bivalves $[3,9,10]$. Among the etiological agents, bacteria from the clade Splendidus have been repeatedly described in relation to mortality events. This polyphyletic group include 16 species with contrasted pathotypes [11,12]. Different strains have been implicated in mortalities of various bivalves, e.g. the Pacific oyster Crassostrea gigas [13-17], the Atlantic scallop Pecten maximus [18,19], the carpet shell clam Ruditapes philippinarum [20], the greenshell mussel Perna canaliculus [21] and recently the blue mussel Mytilus edulis [11].

While infection mechanisms are well studied in human invaders, little is known in the specific case of invertebrate pathogens. Some results have been gathered in different species, especially concerning host-pathogen interactions [11,22-24]. However, invasion processes remain poorly documented. Understanding infection dynamics is an essential step for developing diseases management strategies [25]. In particular, there is a need for robust and standardized experimental models of Vibrio-bivalve interactions.

In a previous work, from mortality events reported by mussel farmers, we have isolated a Vibrio strain virulent to the blue mussel. V. splendidus 10/068 1T1 has been shown to alter hemocyte phagocytosis capacities, a key parameter of the immune defense system in mussels. Furthermore, a stable GFP-tagged Vibrio strain was constructed to facilitate the study of interactions between the microorganism and immune cells [11]. Fluorescent proteins (FP)tagged microorganisms constitute a useful tool to monitor colonization processes. They have been used to elucidate early invasion events in squids [26,27] and bacterial dynamics in filter feeding oysters [28]. 
In the present study, we have investigated infection dynamics of $V$. splendidus 10/068 1T1 in Mytilus edulis. We describe (i) the development of an experimental infection model by water tank cohabitation with septic mussels, (ii) the localization of GFP bacteria in infected animals with the corresponding tissue lesions and (iii) in vitro/in vivo interactions between the pathogenic Vibrio strain and Mytilus edulis hemocytes.

\section{Material and methods}

\subsection{Mussel collection}

Adult mussels, M. edulis with shell length ranging from 4 to $5 \mathrm{~cm}$, were collected on the intertidal rocky shore of Yport ( $0^{\circ} 18^{\prime} 52^{\prime \prime E}: 49^{\circ} 44^{\prime} 30^{\prime \prime N}$, France) between December 2015 and March 2016, immediately transported to the laboratory and placed in a temperature-controlled $\left(10^{\circ} \mathrm{C}\right)$ aerated Biotop Nano Cube 60 seawater tank (Sera, Heinsberg, Germany), equipped with mechanical and activated biological filtering. The animals were fed with algae (Isochrysis galbana) and maintained in these conditions for at least one week before use.

\subsection{Bacterial strains and culture conditions}

Two parental and GFP-tagged $V$. splendidus-related strains were used in this study: a virulent V. splendidus 10/068 1T1 isolated from mussel mortality events reported by professional (French national surveillance network REPAMO) in 2010 and an innocuous V. splendidus 12/056 M24T1 isolated from mussel microflora in absence of mortality in the context of Bivalife European project in 2012 [11]. Bacteria were routinely cultivated overnight in LBS [Luria Bertani complemented with salt, $\mathrm{NaCl} 20$ g.L $\mathrm{L}^{-1}$ (f.c.)] at $22^{\circ} \mathrm{C}$. Stock cultures were stored at $-80^{\circ} \mathrm{C}$ in LBS with glycerol $15 \%$ (v/v) supplemented with kanamycin $100 \mu \mathrm{g} . \mathrm{L}^{-1}$ for GFPtagged strains.

\subsection{In vitro hemocyte challenge}

\subsubsection{Hemolymph collection}

Hemolymph was withdrawn from the posterior adductor muscle sinus, by gentle aspiration with a $1 \mathrm{~mL}$ syringe equipped with a $22 \mathrm{G}$ needle. Quality of samples was systematically checked by microscopic observation before using in bioassays. Samples containing protozoa, tissue fragments, low number of hemocytes were discarded.

\subsubsection{Hemocyte adhesion}

Cells were incubated with bacteria at a ratio of 10 bacteria/hemocyte, or with sterile physiological water $\left(\mathrm{NaCl} 9\right.$ g.L $\left.\mathrm{L}^{-1}\right)$, in a 24-well tissue-culture plates (Greiner). After 2, 4 and 
1206 hours at $15^{\circ} \mathrm{C}$, the number of non adherent cells in the supernatant was counted by flow 121 cytometer.

\subsubsection{Acidic vacuole formation}

123 Crude hemolymph was placed into individual wells of 24-well tissue-culture plates (Greiner)

124 for cytometry or in $35 \mathrm{~mm} \mu$-Dish (Ibidi) for microscopy. Cells were exposed to Vibrio strains 125 at 10:1 ratio (bacteria:hemocytes) for 2 hours at $15^{\circ} \mathrm{C}$.

126 Lysotracker (LysoTracker® Green DND-26, life technologies) at $2 \mu \mathrm{M}$ was added and cells 127 were incubated for 30 minutes at $15^{\circ} \mathrm{C}$ in the dark. Hemocyte fluorescence was quantified by 128 flow cytometry. For microscopy imaging, cells were washed with the marine physiological 129 saline solution [MPSS (470 mM NaCl, $10 \mathrm{mM} \mathrm{KCl}, 10 \mathrm{mM} \mathrm{CaCl}_{2}, 10 \mathrm{mM}$ HEPES, $48,7 \mathrm{mM}$ $\left.130 \mathrm{MgSO}_{4}\right), \mathrm{pH} 7.8,0.2 \mu \mathrm{m}$ filtered]. Hemocyte nuclei were counterstained with hoechst 33342 (5 $131 \mu \mathrm{M}, 15 \mathrm{~min})$ and imaged by epifluorescence microscopy.

\section{$132 \quad$ 2.3.4. Hemocyte viability}

133 Hemocytes were exposed to bacteria (10/068 1T1 and 12/056 M24T1) at $10^{8} \mathrm{CFU}_{\mathrm{mL}}{ }^{-1}$ for 134 different time periods $(2,4,6,18$ and $24 \mathrm{~h})$ at $15^{\circ} \mathrm{C}$. At each time point, propidium iodide was 135 added $(20 \mu \mathrm{M})$ and cell viability was measured by flow cytometry.

136

137

138

139

140

\subsection{In vivo challenge}

\subsubsection{Mussel infection by water tank cohabitation model}

Bacteria were prepared at $\mathrm{OD}_{600 \mathrm{~nm}}$ of 1 as described in Ben Cheikh et al. [11]. Animals were anesthetized for $2-3 \mathrm{~h}$ at $16^{\circ} \mathrm{C}$ in a magnesium chloride solution $\left(50\right.$ g. $\mathrm{L}^{-1}, 1 / 4$ : v/v seawater/freshwater) under aeration. Subsequently, a volume of $100 \mu \mathrm{L}$ of bacterial suspension $\left(2.10^{8}\right.$ CFU. $\left.\mathrm{mL}^{-1}\right)$ or filtered sterile seawater (FSSW) for the negative control was injected into the posterior adductor muscle. After injection, the animals were transferred to tanks ( 3 replicate tanks, 10 mussels per tank) filled with $2 \mathrm{~L}$ of UV-treated and filtered seawater supplemented with $50 \mathrm{~mL}$ of phytoplankton (Isochrysis galbana). After 24 hours, moribund animals were sacrificed by severing their adductor muscle and placed in cohabitation with a group of 10 apparently healthy mussels. For the negative control, mussels injected with FSSW (alive) were sacrificed and used in the same conditions. After 72 hours of cohabitation, injected mussels were removed. During the experiment, animals were maintained under static conditions at $16^{\circ} \mathrm{C}$ with aeration. Mortality was monitored each day over a six days period. Animals were considered to be dead when the valves did not close following stimulation. Newly dead mussels were removed from the tanks. 


\subsubsection{Bacteria counting in seawater}

153 Seawater was sampled from cohabitation tanks each day during the experiment period. $100 \mu \mathrm{L}$ of samples serially diluted in sterile physiological water $\left(\mathrm{NaCl} 9\right.$ g.L $\left.\mathrm{L}^{-1}\right)$ was plated on LBS agar supplemented with kanamycin $100 \mu \mathrm{g} . \mathrm{L}^{-1}$. After $48 \mathrm{~h}$ at $22^{\circ} \mathrm{C}$, colonies were counted. The presence of GFP colonies was verified under a fluorescence stereo microscope (Leica microsystems).

\subsubsection{Hemocyte cellular parameters analysis}

Hemolymph was sampled from exposed mussels and mixed with cold Alsever's solution (300 $\mathrm{mM} \mathrm{NaCl}, 100 \mathrm{mM}$ Glucose, $30 \mathrm{mM}$ sodium Citrate, $26 \mathrm{mM}$ citric acid, $10 \mathrm{mM}$ EDTA, $\mathrm{pH}$ 5.4) for cytometry analysis.

Variation in hemocyte count and the percentage of cells containing GFP-tagged bacteria was determined. Cell viability was investigated by adding propidium iodide $(20 \mu \mathrm{M})$.

\subsubsection{Histological and Immunohistochemical analyses}

165 During cohabitation infection, mussels were sampled at different time periods and removed

166 from their shell. Tissues were fixed in Davidson's solution (20\% formaldehyde 36\%, 30\% 167 FSSW, 10\% glycerol, 30\% ethanol 95\% and 10\% acetic acid) for 48h, dehydrated in a graded 168 series of ethanol, and embedded in paraffin. Consecutive 3-5 $\mu \mathrm{m}$ thick sections were adhered 169 to Superfrost [hematoxylin-eosin (HE) staining] or Superfrost Plus [immunohistochemistry 170 (IHC)] microscope slides.

171 For tissue examination, sections were stained by classical hematoxylin-eosin protocol. Presence 172 of listed pathogens (Bonamia sp., Marteilia sp., Perkinsus sp. and Mikrocytos sp.) was 173 examined as well as trematods, copepods, Mytilicola, ciliates and gregarines. For lesions, we 174 noticed the presence of necrosis, bacterial "foyer", hemocytes infiltration and granulomas into 175 the different tissues: gills, gonads, digestive glands, mantle, muscle, kidney and digestive tube. 176 The lesions in each organ were coded as follows: 0 (absence of lesion); 1 (low), 2 (moderate), 1773 (high). "Low" corresponds to at least one observation in 20 fields of the slide, "moderate" 178 corresponds to at least 5 observations in 10 fields of the slide and "high" corresponds to at least 17910 observations in 10 fields of the slide.

180 For IHC, a polyclonal antibody raised in rabbit against recombinant full length GFP protein 181 was used (Ab290, Abcam). The specificity of this antiserum has been previously tested and 182 optimized. Immuno-labellings were performed with a Benchmark automate (Ventana-Roche) 183 by Histalim (Montpellier). Sections were incubated for 32 min with primary antibody (1:5000) 184 and revealed with Ultraview Red Alkaline Phosphatase kit (Roche Diagnostics). Slides were 
185 finally numerized with a Nanozoomer x20 (Hamamatsu). Labeling of bacterial-like cells was 186 coded following the same criteria used for lesion observations: 0 (absence of labelling); 1 (low), 1872 (moderate), 3 (high).

\section{$188 \quad$ 2.5. Statistical analyses}

189 Statistical analysis was performed by using SigmaPlot 12 (Systat Software Inc., Chicago, IL).

190 Replicates were averaged and the values were tested for normality (Shapiro-Wilk) and paired 191 comparisons were performed by Student's t-tests or by Mann-Whitney rank sum tests in case of 192 unequal variance. Statistical significance was accepted for $* \mathrm{p}<0.05, * * \mathrm{p}<0.01$ or $* * * \mathrm{p}<$ 1930.001

194 3. Results

\section{3.1. Hemocyte adhesion}

196 The effect of V. splendidus-related strains on hemocyte-substrate adhesion was evaluated in 197 vitro for different time of incubation (Figure 1). Hemocyte attachment to the culture dish was 198 significantly affected after $2 \mathrm{~h}$ of exposure to the virulent $V$. splendidus $10 / 068$ 1T1. Moreover, 199 the number of detached hemocytes increased for $6 \mathrm{~h}$ incubations. In contrast, when exposed to the innocuous Vibrio strain 12/056 M24T1, non-adherent cells increased slightly after 2h exposure and then decreased.

\subsection{Acidic vacuole formation}

203 The capacity of M. edulis hemocytes to generate phagolysosome proliferation after exposure to 204 virulent and non-virulent bacteria in vitro was investigated by flow cytometry and epifluorescence microscopy (Figure 2). The lysotracker signal, indicative of acidic vacuole formation, was significantly higher in hemocytes challenged with the strain 12/056 M24T1 than in cells co-cultured with the strain 10/068 1T1 ( $<<0.001$, Figure 2a). Moreover, in the case of exposure to 12/056 M24T1, numerous phagolysosomic compartments surrounding the nucleus can be found (Figure 2b). Microscopic observation also confirmed the absence of large acidic compartments in cells challenged with the virulent strain.

\section{3.3. Hemocyte viability}

212 Hemocyte viability was monitored after exposure to $V$. splendidus- related strains for different 213 time durations. Cell viability was stable during the first 6 hours for both strains with values 214 corresponding to $92 \%$ of viable cells (Figure 3). Then, hemocyte viability slightly decreased 215 until 24h post exposure to the innocuous strain 12/056 M24T1, but was never lower than $80 \%$. 216 In contrast, for the same time periods, the viability of cells incubated with the strain 10/068 1T1 
was significantly affected, reaching a percentage of viable cells of only $59 \%$ after $24 \mathrm{~h}$ exposure 218 to the virulent strain.

\section{$219 \quad$ 3.4. Vibrio infection by cohabitation challenge}

220 Experimental infection of mussels with the pathogenic $V$. splendidus 10/068 1T1 was obtained 221 by water tank cohabitation assays. First mortalities appeared after 3 days (16.6\%) and increased 222 progressively to reach almost $45 \%$ at the $6^{\text {th }}$ day (Figure 4). No mortality was observed in 223 control tanks.

\section{3.5. Seawater bacteria count during infection}

225 Bacteria seawater density in cohabitation tanks was monitored during infection (Figure 5). 226 After $48 \mathrm{~h}$ of cohabitation, the Vibrio density reached $3.10^{6} \mathrm{CFU} / \mathrm{mL}$, then decreased 227 progressively to $2.10^{3} \mathrm{CFU} / \mathrm{mL}$ after 5 days.

\subsection{Hemocyte parameters analysis during the experimental infection}

Different hemocyte parameters were investigated during cohabitation assays with septic mussels infected by the virulent strain 10/068 1T1 (Figure 6). In hemolymph sampled from the adductor muscle, the total hemocyte count increased significantly $48 \mathrm{~h}$ after the cohabitation onset and then decreased until the end of the exposure to reach control values (Figure 6a).

233 Interestingly, GFP bacteria were detected in hemocytes. The percentage of cells containing 234 GFP-tagged Vibrio was also higher at the beginning of the exposure and then decreased progressively (Figure 6b). Furthermore, hemocyte viability slightly decreased compared to the control but remained almost stable during Vibrio infection (80\% of viable cells at day 2 and $74 \%$ at day 5, Figure $6 \mathbf{c})$.

\section{$238 \quad 3.7 . \quad$ Tissue infection by bacteria}

239 GFP-Vibrios were detected mainly in gills of 8 out of 31 live animals and 9 out of 9 moribund animals, either in the pallial cavity, forming aggregates, attached to apical cilia or between ordinary gill filaments (Figure 7A, C). Some labeling were also noticed in esophagi or stomach

242 of 4 out of 28 live animals (Figure 7D). Main observed lesions correspond to necrosis of 243 epithelia (gills and digestive tissues, respectively 30 and 8 out of 40 animals) and hemocyte 244 infiltrations (17 out of 40 animals), as well as granulomas in the mantle (17 out of 40 animals) 245 (Figure 7B, supplementary figure 1C-E, Table 1). Moribund animals contained bacteria in 246 large amounts and presented general necrosis patterns even if some organs were obviously not affected (muscle, gonad, kidney and mantle) (Figure 7B, Table 1). 
248 Some trematodes metacerca in 36 out of 40 animals, copepods in 3 out 40 animals, ciliates in 24928 out of 40 animals or gregarines in 7 out of 40 animals, were noticed (supplementary figure 1, Table 1). However, the most noticeable microorganism present on hematoxylin-eosin strained slides corresponds to bacteria. Seventeen of the 40 analyzed individuals present bacterial cells into gills ( 8 low amount, 6 moderate and 3 high). Bacteria were also noticed in digestive tissues (10 individuals -6 low and 4 moderate) and mantle ( 9 individuals -3 low and 6 moderate) (supplementary figure 1D, Table 1). No listed parasites were found in the 40 mussels (19 females and 21 males).

\section{Discussion}

In a previous study, we have reported the virulence of $V$. splendidus 10/068 $1 \mathrm{~T} 1$ to the blue mussel and its capacity to alter the host immune response [11]. Herein, we expand the knowledge on mussel-pathogen interactions by exploring infection dynamics via water tank cohabitation experimental model and by studying hemocyte responses via in vitro/in vivo assays.

\subsection{In vitro hemocyte-pathogen interactions}

To elicit cell-mediated immune responses, adhesion phenomena are crucial. In our experiments,

264 V. splendidus 10/068 1T1 severely altered hemocyte attachment to the culture substratum. After 2 hours of incubation in the presence of the virulent Vibrio, the number of non-adherent cells was higher than in non-treated cultures or in cells co-incubated with the innocuous bacteria. This effect increased after $6 \mathrm{~h}$ of exposure to V. splendidus 10/068 1T1. Similar observations were made for other Vibrio species with bivalve hemocytes. For example, V. tasmaniensis LGP32 decreased hemocyte adhesion capacity in Mytilus edulis [29], Mytilus galloprovincialis [30] and Mya arenaria [31]. The same response was reported for Crassostrea gigas hemocytes challenged with $V$. aestuarianus 01/32 [32] and cells of Ruditapes philippinarum in contact with $V$. tapetis [33]. Despite the robustness of these observations, specific mechanisms by which a pathogen induces hemocyte detachment from adhesion surfaces remain poorly understood. Some studies suggested the involvement of proteases secreted by the bacteria and responsible for disruption of cytoskeleton, cell adhesion molecules and extracellular matrix components. In the Pacific oyster, hemocyte treatment with extracellular products (ECPs) of $V$. aestuarianus 01/32 or V. tubiashii 07/118 T2 inhibited cell binding to culture dish [34,35]. Furthermore, the hydrolytic action of extracellular effectors capable to degrade muscle collagen, bovine actin and fibronectin proteins has been shown [35]. In addition of abolishing hemocyte attachment to substrate, alteration of immunocyte adhesion capabilities by ECPs also 
281 probably affects phagocyte activity. In this regard, we have previously shown that ECPs from

282 V. splendidus 10/068 1T1 inhibit M. edulis hemocyte phagocytosis [11].

283 Upon entrance into hemocytes, the fate of bacteria depends on phagosome biogenesis and 284 maturation. Intracellular trafficking and killing of engulfed microorganisms is a highly 285 choreographed process driven by subsequent fusion and fission events during which the 286 maturing phagosome acquires the characteristics of degradative acidic lysosomes [36,37]. In 287 our study, V. splendidus 10/068 1T1 inhibited acidic vacuole formation in mussel hemocytes 288 while the innocuous phylogenetically related to $V$. splendidus 12/056 M24T1 had no effect. 289 Such mechanism has been described for intracellular pathogens as strategy to survive and 290 maintain infection within cells. This is the case of Legionella pneumophila, the causative agent 291 of Legionnaire's pneumonia, known for its ability to manipulate host cell vesicular trafficking 292 pathways and to inhibit phagosome-lysosome fusion [38,39]. In the same way, Mycobacterium 293 sp. reside inside vacuoles and arrest the fusion with late endosomal/lysosomal organelles [40, 294 41]. For Vibrio species, few reports have shown their capacity to adopt intracellular stages [42295 44]. To our knowledge, only V. tasmaniensis LGP32 has been described as a facultative 296 intracellular pathogen of the Pacific oyster, able to modulate phagosome maturation as well as 297 oxidative response [24]. More recently, Vanhove et al. [45] showed the intracellular surviving 298 of this strain until hemocyte cytolysis (more than $25 \%$ of cell lysis after $17 \mathrm{~h}$ incubation). In 299 accordance with these findings, it seems that $V$. splendidus 10/068 1T1 displays a similar 300 infection strategy to $V$. tasmaniensis LGP32. Besides altering phagosome maturation and ROS 301 production [11], this Mytilus edulis pathogen affected hemocyte viability and induced almost 302 $39 \%$ of dead cells after $18 \mathrm{~h}$. The latter point prove the cytotoxicity of the bacteria and suggests its surviving into the cells.

\subsection{In vivo infection dynamics}

Understanding pathogenesis processes requires an animal model of infection [46]. In our previous study, we have demonstrated the virulence of $V$. splendidus 10/068 1T1 towards the blue mussel by injection [11]. In spite its efficacy and repeatability, this method does not reflect the realistic way of host-bacteria interaction. Herein, we successfully reproduced experimental infection by cohabitation assays. In these experimental conditions, first mortalities appeared after 3 days and increased progressively suggesting a necessity of time for bacteria transfer

311 from diseased animals and the occurrence of a latency period in healthy mussels. At the same 312 time intervals, the amount of GFP-Vibrio released in the seawater decreased $\left(3.10^{6} \mathrm{CFU} / \mathrm{mL}\right.$ at 313 the $2^{\text {nd }}$ day to $2.10^{3} \mathrm{CFU} / \mathrm{mL}$ at the $6^{\text {th }}$ day). In addition to probable adhesion/penetration into 
314 its host, this decline could result from bacteria mortality or adhesion to tank walls. Though,

315 Vibrio were also detected in healthy mussel tissues confirming a transmission of a part of them 316 from infected animals during the cohabitation period.

317 Up to now, only few works have investigated non-invasive methods for the study of infectious 318 diseases in bivalves and they were limited to Pacific oysters. In this model, successful 319 experimental vibriosis were induced by cohabitation $[47,48]$ or by immersion assays [49]. In 320 our case, unlike cohabitation experiments, the bathing procedure did not cause any mortality 321 (data not shown). This negative result reveals the complexity of infection process. Bacteria may 322 require a priming infectious niche or a cooperation with mussel microflora to initiate some 323 virulence mechanisms [50].

324 During experimental infection, the number of circulating cells temporary increased at day 2 325 post-challenge and then stabilized to a value not distinct from control. Similar transient hemocytosis have been described in diverse bivalve species like M. edulis [51], M. galloprovincialis [52] and $R$. philippinarum [53] in response to physical stresses or pathogen threats. Such variation in circulating hemocytes have been explained by cell proliferation [51]. Mobilizations of peripheral hemocytes from tissues consecutively to bacterial infection were also evoked to account for by a transient increase of circulating cells [32,53]. Inversely, back infiltration of infected sites by hemocytes could explain a consecutive decrease of total hemocyte count in hemolymph. Alternatively, the decrease of cell concentration observed secondarily to hemocytosis can also originate from a Vibrio induced hemocyte death. The hypothesis get confirmation from our experiments showing a loss of viability both for hemocytes exposed to Vibrio in vitro and for hemocytes withdraw from infected animals. It is also in good agreement with mortalities observed after 3 days of cohabitation with septic mussels. Furthermore, V. splendidus 10/068 1T1 was detected in hemocytes and the population of bacteria-containing hemocyte declined progressively with time. The latter result is probably coherent with a pathogenicity involving a phagocyte lysis and a bacteria release.

340 In addition to hemocyte parameters analysis, histology was performed on infected mussels. 341 Many organisms were identified in tissues of living and moribund mussel (trematodes, 342 copepods, Ciliophora, ciliates and gregarines). The presence of parasites is not surprising since 343 animals were collected from natural areas. Their potential interaction with pathogens are still 344 unknown. GFP-Vibrio were localized in diverse organs and obviously caused necrosis of 345 digestive gland and gills principally. Data concerning bacterial diseases in bivalves indicate that 346 infections are initiated at mucosal interfaces [54]. Nevertheless, in order to establish a 
chronology, the entry route of bacteria has to be identified. Few studies explored portal access

348 of pathogens in bivalves. For example, the organic matrix of the shell has been described as a putative entryway of the pathogenic $V$. tapetis in the clam $R$. philippinarum [55,56]. More recently, a study suggested the involvement of hemocytes in microbe transport because of their ability to migrate across mucosal epithelia and to translocate within hours from pallial surfaces to underlying tissues and to the circulatory system [54]. This hypothesis may be plausible in our study considering the cytotoxicity of $V$. splendidus 10/068 1T1 to hemocytes. Further investigations at the first hours of infection are needed to elucidate whether hemocytes are the first or the last target of pathogens.

\section{Conclusion}

V. splendidus 10/068 1T1 has been previously reported to be pathogenic to the blue mussel. In this study, we first investigated hemocyte-bacteria interactions. In vitro challenges demonstrate the capacity of Vibrio strain to alter the maturation of the phagolysosome, the cell adhesion and viability. Then, we successfully established a non-invasive experimental infection model via cohabitation. Bacteria were able to bypass defense barriers and were detected in diverse organs and in hemocytes. The number and the viability of circulating hemocytes were altered. Taken together, our results confirm the virulence of V. splendidus 10/068 1T1 towards M. edulis hemocytes and suggest the use of immune cells as pathogen vehicles to spread the infection in the whole organism. Furthermore, besides the description of an original infection process, this study can be useful to be compared with natural mortalities occurred in the field.

\section{Acknowledgements}

This work received fundings from the State/Region Plan Contract (CPER) allocated through the Research Federation FR CNRS 3730 SCALE /FED 4116 SCALE (Sciences Appliquées à L'Environnement), and DGAl support through National Reference Laboratory activities for mollusc diseases (Ifremer-La Tremblade). Yosra Ben Cheikh was a recipient for a Ph.D. grant

372 from the Conseil Regional de Haute-Normandie. The authors are indebted to the marine fish farm Aquacaux (Octeville, France) and Histalim (Montpellier, France) for valuable technical assistance.

\section{References}


[1] Thompson, F.L., Iida, T., Swings, J., 2004. Biodiversity of Vibrios. Microbiol. Mol. Biol. Rev. 68, 403-431. doi:10.1128/MMBR.68.3.403-431.2004

[2] Hasan, N.A., Grim, C.J., Lipp, E.K., Rivera, I.N.G., Chun, J., Haley, B.J., Taviani, E., Choi, S.Y., Hoq, M., Munk, A.C., Brettin, T.S., Bruce, D., Challacombe, J.F., Detter, J.C., Han, C.S., Eisen, J.A., Huq, A., Colwell, R.R., 2015. Deep-sea hydrothermal vent bacteria related to human pathogenic Vibrio species. Proc. Natl. Acad. Sci. 112, E2813E2819. doi:10.1073/pnas.1503928112

[3] Travers, M.-A., Boettcher Miller, K., Roque, A., Friedman, C.S., 2015. Bacterial diseases in marine bivalves. J. Invertebr. Pathol. doi:10.1016/j.jip.2015.07.010

[4] Feldhusen, F., 2000. The role of seafood in bacterial foodborne diseases. Microbes Infect. 2, 1651-1660. doi:10.1016/S1286-4579(00)01321-6

[5] Powell, J.L., 1999. Vibrio species. Clin. Lab. Med. 19, 537-552, vi.

[6] Colwell, R.R., Grimes, D.J., 1984. Vibrio diseases of marine fish populations. Helgoländer Meeresunters. 37, 265-287. doi:10.1007/BF01989311

[7] Ben-Haim, Y., Rosenberg, E., 2002. A novel Vibrio sp. pathogen of the coral Pocillopora damicornis. Mar. Biol. 141, 47-55. doi:10.1007/s00227-002-0797-6

[8] Goarant, C., Ansquer, D., Herlin, J., Domalain, D., Imbert, F., De Decker, S., 2006. "Summer Syndrome" in Litopenaeus stylirostris in New Caledonia: Pathology and epidemiology of the etiological agent, Vibrio nigripulchritudo. Aquaculture 253, 105113. doi:10.1016/j.aquaculture.2005.07.031

[9] Paillard, C., Le Roux, F., Borrego, J.J., 2004. Bacterial disease in marine bivalves, a review of recent studies: Trends and evolution. Aquat. Living Resour. 17, 477-498. doi:10.1051/alr:2004054

[10] Beaz-Hidalgo, R., Balboa, S., Romalde, J.L., Figueras, M.J., 2010a. Diversity and pathogenecity of Vibrio species in cultured bivalve molluscs. Environ. Microbiol. Rep. 2, 34-43. doi:10.1111/j.1758-2229.2010.00135.x

[11] Ben Cheikh, Y., Travers, M.-A., Morga, B., Godfrin, Y., Rioult, D., Le Foll, F., 2016. First evidence for a Vibrio strain pathogenic to Mytilus edulis altering hemocyte immune capacities. Dev. Comp. Immunol. 57, 107-119. doi:10.1016/j.dci.2015.12.014

[12] Kwan, T.N., Bolch, C.J.S., 2015. Genetic diversity of culturable Vibrio in an Australian blue mussel Mytilus galloprovincialis hatchery. Dis. Aquat. Organ. 116, 37-46. doi:10.3354/dao02905

[13] Bruto, M., James, A., Petton, B., Labreuche, Y., Chenivesse, S., Alunno-Bruscia, M., Polz, M.F., Le Roux, F., 2017. Vibrio crassostreae, a benign oyster colonizer turned into a pathogen after plasmid acquisition. ISME J. 11, 1043-1052. doi:10.1038/ismej.2016.162

[14] Gay, M., Berthe, F.C.J., Le Roux, F., 2004. Screening of Vibrio isolates to develop an experimental infection model in the Pacific oyster Crassostrea gigas. Dis. Aquat. Organ. 59, 49-56. doi:10.3354/dao059049

[15] Lacoste, A., Jalabert, F., Malham, S., Cueff, A., Gélébart, F., Cordevant, C., Lange, M., Poulet, S.A., 2001. A Vibrio splendidus strain is associated with summer mortality of juvenile oysters Crassostrea gigas in the Bay of Morlaix (North Brittany, France). Dis. Aquat. Organ. 46, 139-145. doi:10.3354/dao046139

[16] Lemire, A., Goudenège, D., Versigny, T., Petton, B., Calteau, A., Labreuche, Y., Le Roux, F., 2015. Populations, not clones, are the unit of Vibrio pathogenesis in naturally infected oysters. ISME J. 9, 1523-1531. doi:10.1038/ismej.2014.233

[17] Saulnier, D., De Decker, S., Haffner, P., Cobret, L., Robert, M., Garcia, C., 2010. A large-scale epidemiological study to identify bacteria pathogenic to Pacific oyster Crassostrea gigas and correlation between virulence and metalloprotease-like activity. Microb. Ecol. 59, 787-798. doi:10.1007/s00248-009-9620-y 
[18] Lambert, C., Nicolas, J.L., Cilia, V., 1999. Vibrio splendidus-related strain isolated from brown deposit in scallop (Pecten maximus) cultured in Brittany (France). Bull Eur Fish Pathol 102.

[19] Nicolas, J.L., Corre, S., Gauthier, G., Robert, R., Ansquer, D., 1996. Bacterial problems associated with scallop Pecten maximus larval culture. Dis. Aquat. Org. 27, 67-76. doi:10.3354/dao027067

[20] Beaz-Hidalgo, R., Diéguez, A.L., Cleenwerck, I., Balboa, S., Doce, A., de Vos, P., Romalde, J.L., 2010b. Vibrio celticus sp. nov., a new Vibrio species belonging to the Splendidus clade with pathogenic potential for clams. Syst. Appl. Microbiol. 33, 311315. doi:10.1016/j.syapm.2010.06.007

[21] Kesarcodi-Watson, A., Kaspar, H., Lategan, M.J., Gibson, L., 2009. Two pathogens of Greenshell mussel larvae, Perna canaliculus: Vibrio splendidus and a $V$. coralliilyticus/neptunius-like isolate. J. Fish Dis. 32, 499-507. doi:10.1111/j.13652761.2009.01006.x

[22] Araya, M.T., Siah, A., Mateo, D.R., Markham, F., McKenna, P., Johnson, G.R., Berthe, F.C.J., 2009. Morphological and molecular Effects of Vibrio splendidus on hemocytes of softshell clams, Mya arenaria. J. Shellfish Res. 28, 751-758. doi:10.2983/035.028.0403

[23] Balbi, T., Fabbri, R., Cortese, K., Smerilli, A., Ciacci, C., Grande, C., Vezzulli, L., Pruzzo, C., Canesi, L., 2013. Interactions between Mytilus galloprovincialis hemocytes and the bivalve pathogens Vibrio aestuarianus 01/032 and Vibrio splendidus LGP32. Fish Shellfish Immunol. 35, 1906-1915. doi:10.1016/j.fsi.2013.09.027

[24] Duperthuy, M., Schmitt, P., Garzón, E., Caro, A., Rosa, R.D., Le Roux, F., LautrédouAudouy, N., Got, P., Romestand, B., de Lorgeril, J., Kieffer-Jaquinod, S., Bachère, E., Destoumieux-Garzón, D., 2011. Use of OmpU porins for attachment and invasion of Crassostrea gigas immune cells by the oyster pathogen Vibrio splendidus. Proc. Natl. Acad. Sci. U. S. A. 108, 2993-2998. doi:10.1073/pnas.1015326108

[25] Restif, O., Graham, A.L., 2015. Within-host dynamics of infection: from ecological insights to evolutionary predictions. Phil Trans R Soc B 370, 20140304. doi:10.1098/rstb.2014.0304

[26] Nyholm, S.V., Stabb, E.V., Ruby, E.G., McFall-Ngai, M.J., 2000. Establishment of an animal-bacterial association: Recruiting symbiotic Vibrios from the environment. Proc. Natl. Acad. Sci. 97, 10231-10235. doi:10.1073/pnas.97.18.10231

[27] Nyholm, S.V., McFall-Ngai, M.J., 2003. Dominance of Vibrio fischeri in secreted mucus outside the light organ of Euprymna scolopes: the first site of symbiont specificity. Appl. Environ. Microbiol. 69, 3932-3937.

[28] Cabello, A.E., Espejo, R.T., Romero, J., 2005. Tracing Vibrio parahaemolyticus in oysters (Tiostrea chilensis) using a Green Fluorescent Protein tag. J. Exp. Mar. Biol. Ecol. 327, 157-166.

[29] Tanguy, M., McKenna, P., Gauthier-Clerc, S., Pellerin, J., Danger, J.-M., Siah, A., 2013. Functional and molecular responses in Mytilus edulis hemocytes exposed to bacteria, Vibrio splendidus. Dev. Comp. Immunol. 39, 419-429. doi:10.1016/j.dci.2012.10.015

[30] Ciacci, C., Betti, M., Canonico, B., Citterio, B., Roch, P., Canesi, L., 2010. Specificity of anti-Vibrio immune response through $\mathrm{p} 38$ MAPK and PKC activation in the hemocytes of the mussel Mytilus galloprovincialis. J. Invertebr. Pathol. 105, 49-55. doi:10.1016/j.jip.2010.05.010

[31] Mateo, D.R., Siah, A., Araya, M.T., Berthe, F.C.J., Johnson, G.R., Greenwood, S.J., 2009. Differential in vivo response of soft-shell clam hemocytes against two strains of Vibrio splendidus: Changes in cell structure, numbers and adherence. J. Invertebr. Pathol. 102, 50-56. doi:10.1016/j.jip.2009.06.008 
[32] Labreuche, Y., Lambert, C., Soudant, P., Boulo, V., Huvet, A., Nicolas, J.-L., $2006 a$. Cellular and molecular hemocyte responses of the Pacific oyster, Crassostrea gigas, following bacterial infection with Vibrio aestuarianus strain 01/32. Microbes Infect. 8, 2715-2724. doi:10.1016/j.micinf.2006.07.020

[33] Choquet, G., Soudant, P., Lambert, C., Nicolas, J.-L., Paillard, C., 2003. Reduction of adhesion properties of Ruditapes philippinarum hemocytes exposed to Vibrio tapetis. Dis. Aquat. Organ. 57, 109-116. doi:10.3354/dao057109

[34] Labreuche, Y., Soudant, P., Gonçalves, M., Lambert, C., Nicolas, J.-L., 2006b. Effects of extracellular products from the pathogenic Vibrio aestuarianus strain 01/32 on lethality and cellular immune responses of the oyster Crassostrea gigas. Dev. Comp. Immunol. 30, 367-379. doi:10.1016/j.dci.2005.05.003

[35] Mersni-Achour, R., Imbert-Auvray, N., Huet, V., Ben Cheikh, Y., Faury, N., Doghri, I., Rouatbi, S., Bordenave, S., Travers, M.-A., Saulnier, D., Fruitier-Arnaudin, I., 2014. First description of French $V$. tubiashii strains pathogenic to mollusk: II. Characterization of properties of the proteolytic fraction of extracellular products. $J$. Invertebr. Pathol. 123, 49-59. doi:10.1016/j.jip.2014.09.006

[36] Russell, D.G., 2001. Phagocytosis, in: ELS. John Wiley \& Sons, Ltd.

[37] Weiss, G., Schaible, U.E., 2015. Macrophage defense mechanisms against intracellular bacteria. Immunol. Rev. 264, 182-203. doi:10.1111/imr.12266

[38] Horwitz, M.A., 1983. The Legionnaires' disease bacterium (Legionella pneumophila) inhibits phagosome-lysosome fusion in human monocytes. J. Exp. Med. 158, 21082126.

[39] Isberg, R.R., O’Connor, T., Heidtman, M., 2009. The Legionella pneumophila replication vacuole: making a cozy niche inside host cells. Nat. Rev. Microbiol. 7, 1324. doi:10.1038/nrmicro1967

[40] Armstrong, J.A., Hart, P.D., 1971. Response of cultured macrophages to Mycobacterium tuberculosis, with observations on fusion of lysosomes with phagosomes. J. Exp. Med. 134, 713-740.

[41] Russell, D.G., Mwandumba, H.C., Rhoades, E.E., 2002. Mycobacterium and the coat of many lipids. J. Cell Biol. 158, 421-426. doi:10.1083/jcb.200205034

[42] Rosenberg, E., Falkovitz, L., 2004. The Vibrio shiloi/Oculina patagonica model system of coral bleaching. Annu. Rev. Microbiol. 58, 143-159. doi:10.1146/annurev.micro.58.030603.123610

[43] Santos, M. de S., Orth, K., 2014. Intracellular Vibrio parahaemolyticus escapes the vacuole and establishes a replicative niche in the cytosol of epithelial cells. mBio 5, e01506-14. doi:10.1128/mBio.01506-14

[44] Zhang, L., Krachler, A.M., Broberg, C.A., Li, Y., Mirzael, H., Gilpin, C.J., Orth, K., 2012. Type III effector VopC mediates invasion for Vibrio species. Cell Rep. 1, 453460. doi:10.1016/j.celrep.2012.04.004

[45] Vanhove, A.S., Rubio, T.P., Nguyen, A.N., Lemire, A., Roche, D., Nicod, J., Vergnes, A., Poirier, A.C., Disconzi, E., Bachère, E., Le Roux, F., Jacq, A., Charrière, G.M., Destoumieux-Garzón, D., 2016. Copper homeostasis at the host Vibrio interface: lessons from intracellular Vibrio transcriptomics. Environ. Microbiol. 18, 875-888. doi:10.1111/1462-2920.13083

[46] Le Roux, F.L., Wegner, K.M., Polz, M.F., 2016. Oysters and Vibrios as a Model for Disease Dynamics in Wild Animals. Trends Microbiol. 24, 568-580. doi:10.1016/j.tim.2016.03.006

[47] Azéma, P., Travers, M.-A., De Lorgeril, J., Tourbiez, D., Dégremont, L., 2015. Can selection for resistance to OsHV-1 infection modify susceptibility to Vibrio aestuarianus 
infection in Crassostrea gigas? First insights from experimental challenges using primary and successive exposures. Vet. Res. 46. doi:10.1186/s13567-015-0282-0

[48] De Decker, S., Saulnier, D., 2011. Vibriosis induced by experimental cohabitation in Crassostrea gigas: Evidence of early infection and down-expression of immune-related genes. Fish Shellfish Immunol. 30, 691-699. doi:10.1016/j.fsi.2010.12.017

[49] De Decker, S., Normand, J., Saulnier, D., Pernet, F., Castagnet, S., Boudry, P., 2011. Responses of diploid and triploid Pacific oysters Crassostrea gigas to Vibrio infection in relation to their reproductive status. J. Invertebr. Pathol. 106, 179-191. doi:10.1016/j.jip.2010.09.003

[50] Harrison, F., 2013. Bacterial cooperation in the wild and in the clinic: Are pathogen social behaviours relevant outside the laboratory? Bioessays 35, 108-112. doi:10.1002/bies.201200154

[51] Renwrantz, L., Siegmund, E., Woldmann, M., 2013. Variations in hemocyte counts in the mussel, Mytilus edulis: similar reaction patterns occur in disappearance and return of molluscan hemocytes and vertebrate leukocytes. Comp. Biochem. Physiol. A. Mol. Integr. Physiol. 164, 629-637. doi:10.1016/j.cbpa.2013.01.021

[52] Ciacci, C., Citterio, B., Betti, M., Canonico, B., Roch, P., Canesi, L., 2009. Functional differential immune responses of Mytilus galloprovincialis to bacterial challenge. Comp. Biochem. Physiol. B Biochem. Mol. Biol. 153, 365-371. doi:10.1016/j.cbpb.2009.04.007

[53] Allam, B., Paillard, C., Auffret, M., Ford, S.E., 2006. Effects of the pathogenic Vibrio tapetis on defence factors of susceptible and non-susceptible bivalve species: II. Cellular and biochemical changes following in vivo challenge. Fish Shellfish Immunol. 20, 384397. doi:10.1016/j.fsi.2005.05.013

[54] Allam, B., Pales Espinosa, E., 2016. Bivalve immunity and response to infections: Are we looking at the right place? Fish Shellfish Immunol., Special Issue: ISFSI 2016 53, 412. doi:10.1016/j.fsi.2016.03.037

[55] Allam, B., Paillard, C., Ford, S.E., 2002. Pathogenicity of Vibrio tapetis, the etiological agent of brown ring disease in clams. Dis. Aquat. Organ. 48, 221-231. doi:10.3354/dao048221

[56] Paillard, C., Maes, P., 1995. The Brown Ring Disease in the Manila Clam, Ruditapes philippinarum. J. Invertebr. Pathol. 65, 91-100. doi:10.1006/jipa.1995.1015 
568 Figure 1. Effect of V. splendidus-related strains on hemocyte adhesion in vitro. 569 The number of non-adherent cells was evaluated after exposure to the virulent $V$. splendidus $57010 / 068$ 1T1 and to the non-virulent $V$. splendidus 12/056 M24T1 for 2, 4 and 6h. Data are 571 expressed as mean \pm SEM $(n=5)$, * indicates values significantly different from control and $\S$ 572 marks results that significantly differ from values obtained with the non-virulent bacteria 573 12/056 M24T1 (p<0.05, Student's t-test)

574 Figure 2. Acidic vacuole formation in hemocytes after exposure to V. splendidus-related 575 strains. (a) Flow cytometry analysis of hemocytes exposed in vitro to virulent or non-virulent 576 bacteria during $2 \mathrm{~h}$ and incubated $30 \mathrm{~min}$ with lysotracker at $0.4 \mu \mathrm{M}$. Data are expressed as mean 577 of fluorescence \pm SEM, arbitrary units (A.U.), $n=5$. *** indicates values significantly different 578 from control (Student's t-test, p<0.001). (b) Fluorescence microscopy of hemocytes exposed in 579 vitro to virulent or non-virulent bacteria during $2 \mathrm{~h}$ and incubated with lysotracker green $(0.4$ $580 \mu \mathrm{M}, 30 \mathrm{~min})$ and Hoechst 33342 (5 $\mu \mathrm{M}, 15 \mathrm{~min})$.

581 Figure 3. Effect of exposure to bacteria on hemocyte viability in vitro. Hemocytes were 582 incubated with $V$. splendidus-related strains 10/068 1T1 or 12/056 M24T1 for different time 583 durations. Viability was determined by flow cytometry after propidium iodide staining. Data 584 are expressed as mean $\pm \mathrm{SEM}, \mathrm{n}=4$. $* *$ indicates values significantly different from the control $585 \mathrm{p}<0.01$ Student's t-test).

586 Figure 4. Cumulative mortalities recorded after experimental infections of adult mussels by 587 water tank cohabitation with septic mussels. GFP-tagged V. splendidus 10/068 1T1 strain was 588 injected intramuscularly to mussels. $24 \mathrm{~h}$ post injection, moribund animals were sacrificed and 589 placed in cohabitation with healthy mussels for $72 \mathrm{~h}$ and then removed. Cohabitation assays 590 with mussels injected with FSSW were used as control. Data are mean \pm SEM of cumulative 591 mortalities in triplicate tanks.

592 Figure 5. V. splendidus 10/068 1T1 count in water tank seawater during experimental infections 593 in vivo by cohabitation with septic mussels. Seawater was sampled daily during cohabitation 594 assays and plated on LBS kanamycin agar plates. Bacteria concentration was determined over 595 time $(\mathrm{CFU} / \mathrm{mL}$, mean $\pm \mathrm{SEM}, \mathrm{n}=3)$

596 Figure 6. Analysis of hemocyte parameters during experimental infections by $V$. splendidus 597 10/068 1T1 via water tank cohabitation with septic mussels. Hemolymph was sampled over 
598 time from cohabited mussels and (a) absolute hemocyte concentration, (b) percentage of 599 hemocyte containing GFP bacteria and (c) hemocyte viability were monitored by flow 600 cytometry. Data are expressed as mean \pm SEM $(n=4-13)$. Values significantly different from 601 control are indicated $(* \mathrm{p}<0.05, * * \mathrm{p}<0.01 *, * * * \mathrm{p}<0.001$, Student's $\mathrm{t}$-test $)$.

602 Figure 7. Histological observations of mussel tissues during experimental infections by $V$. 603 splendidus 10/068 1T1 via water tank cohabitation with septic mussels. GFP-tagged bacteria 604 were detected by immunohistochemistry (pink labeling). Tissues were counter-stained with 605 hematoxylin. A-C: Gills, D: esophagi and stomach. Scale bars of 50 or $100 \mu \mathrm{m}$ are indicated.

606 Supplementary figure 1. Histological observations of hematoxylin-eosin stained sections of 607 mussel tissues during experimental infections by water tank cohabitation with septic mussels. 608 A. Unidentified trematode in digestive glands (metacerca), B. Mytilicola sp. in digestive lumen, 609 C. Unidentified copepod and hemocytes infiltration in gills, D. Bacteria, ciliates and gill 610 necrosis, E. Digestive glands and esophagi necrosis, F. Inflammatory granulomas. Scale bars 611 of $100 \mu \mathrm{m}, 250 \mu \mathrm{m}, 500 \mu \mathrm{m}$ or $1 \mathrm{~mm}$ are indicated.

612

613

614

615

616

617 
618 Table 1: Histological observations on hematoxylin-eosin stained sections of mussel tissues 619 during experimental infections by water tank cohabitation with septic mussels. Presence of 620 micro-organisms and lesions (as necrosis, infiltrations or granulomas) were noticed and 621 classified in categories $(0,1,2$ or 3$)$ as defined in material and methods section. A total of 40 622 individuals were observed (21 males, 19 females; 38 live sacrificed animals, 9 moribunds). 623 Number of observations is indicated, as well as the number of included moribunds in this 624 count (includ. $\mathrm{xM}=$ including $\mathrm{x}$ moribunds).

625

626 
Figure 1

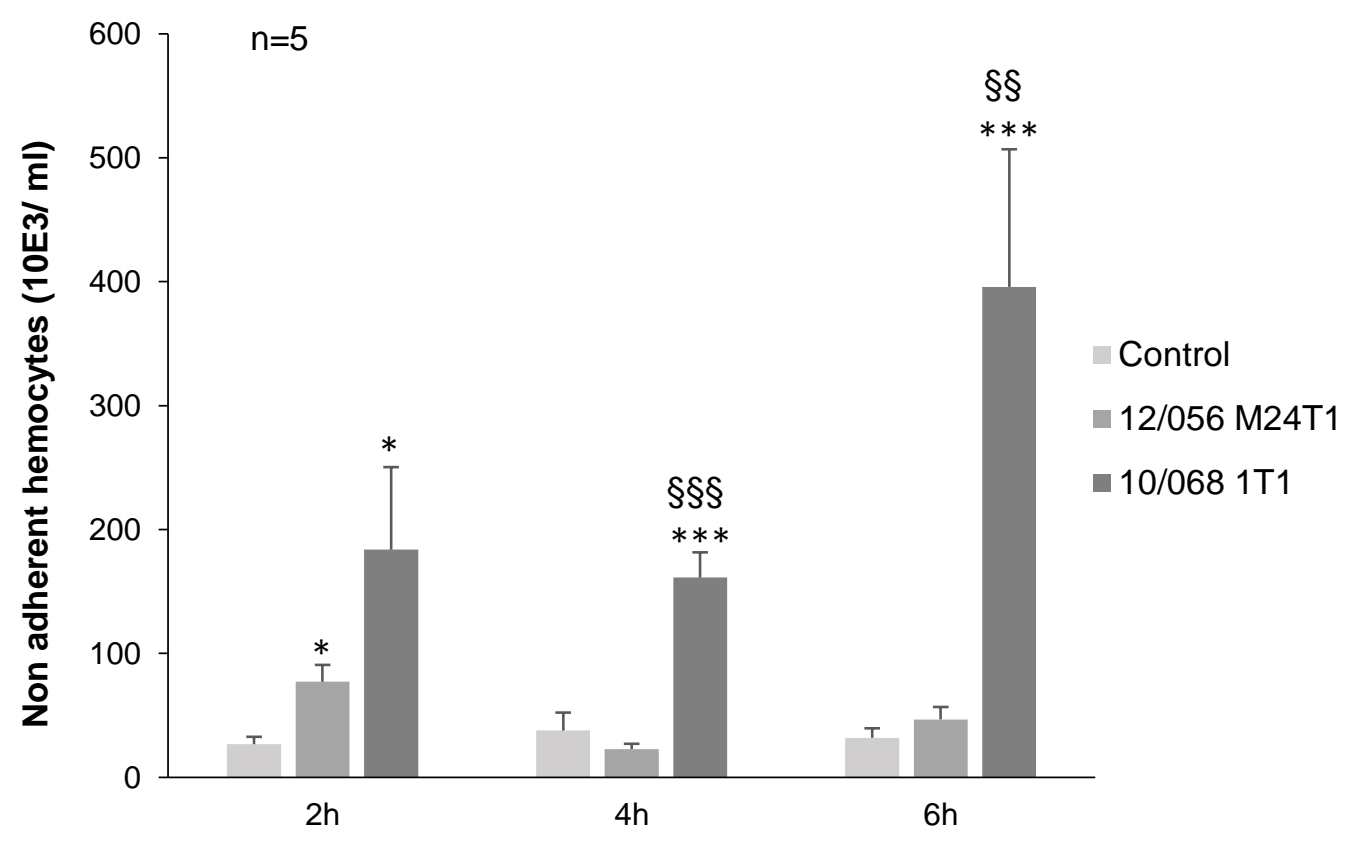


Figure 2

(a)

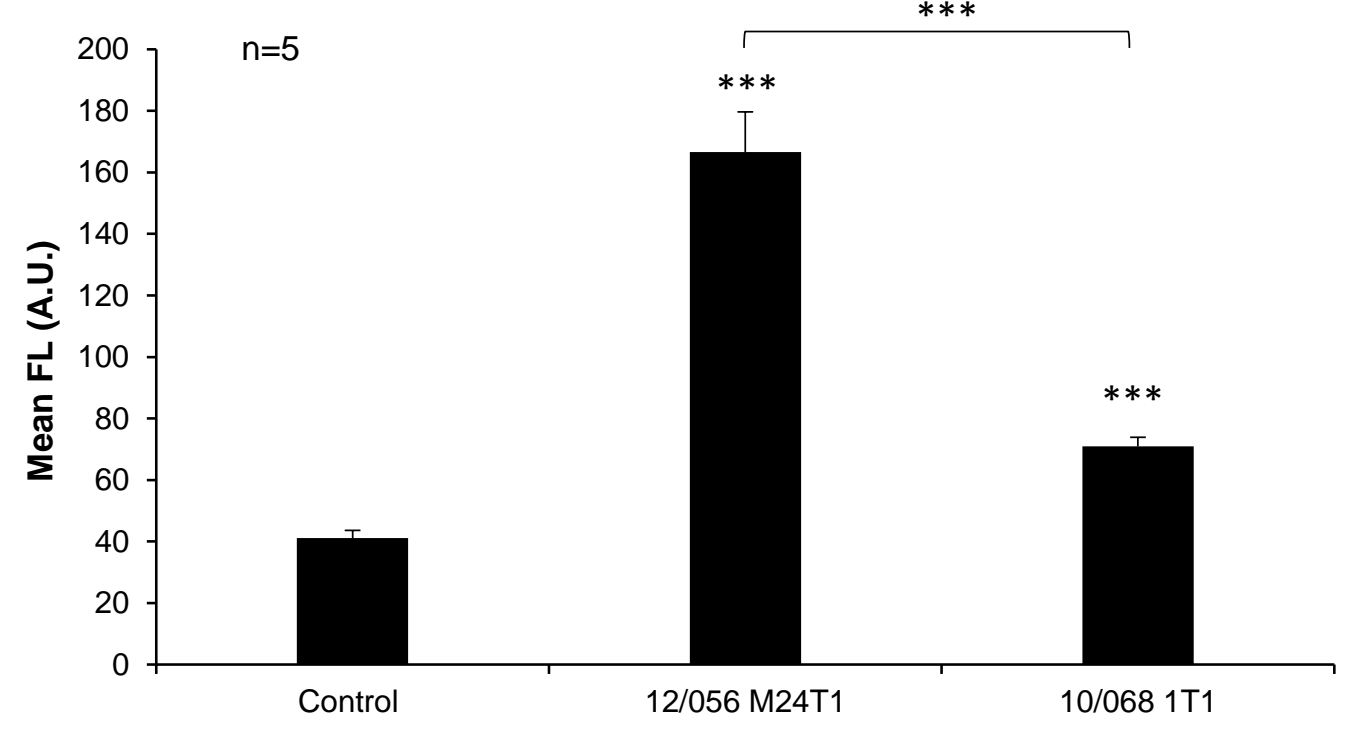

(b)

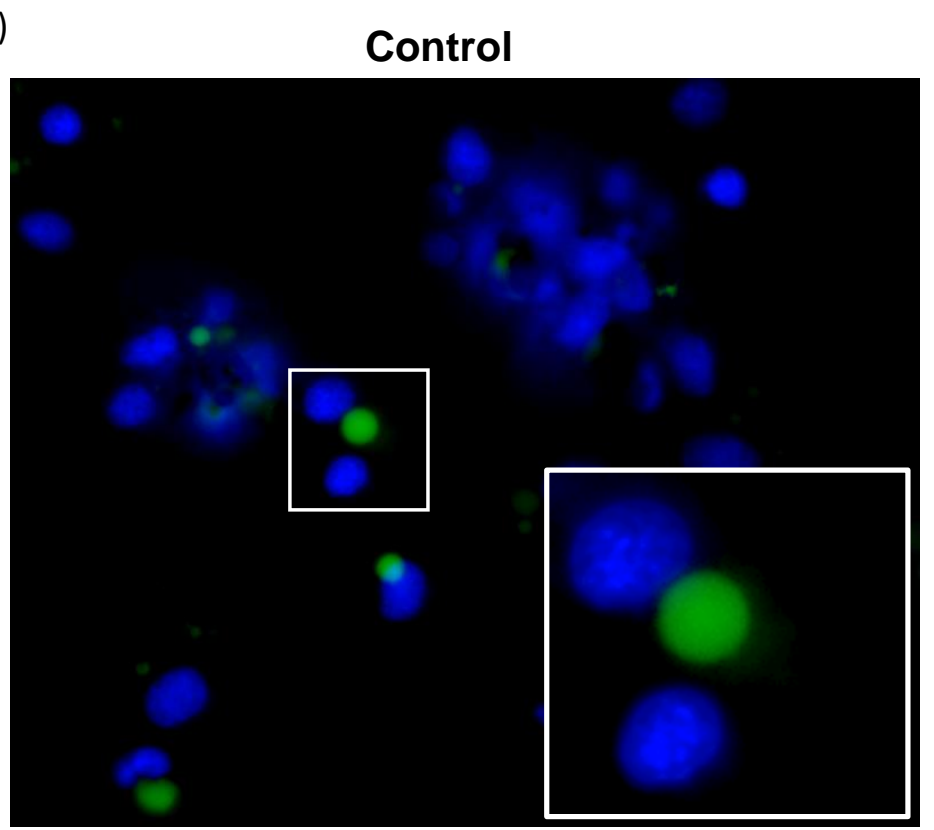

V. splendidus 12/056 M24T1

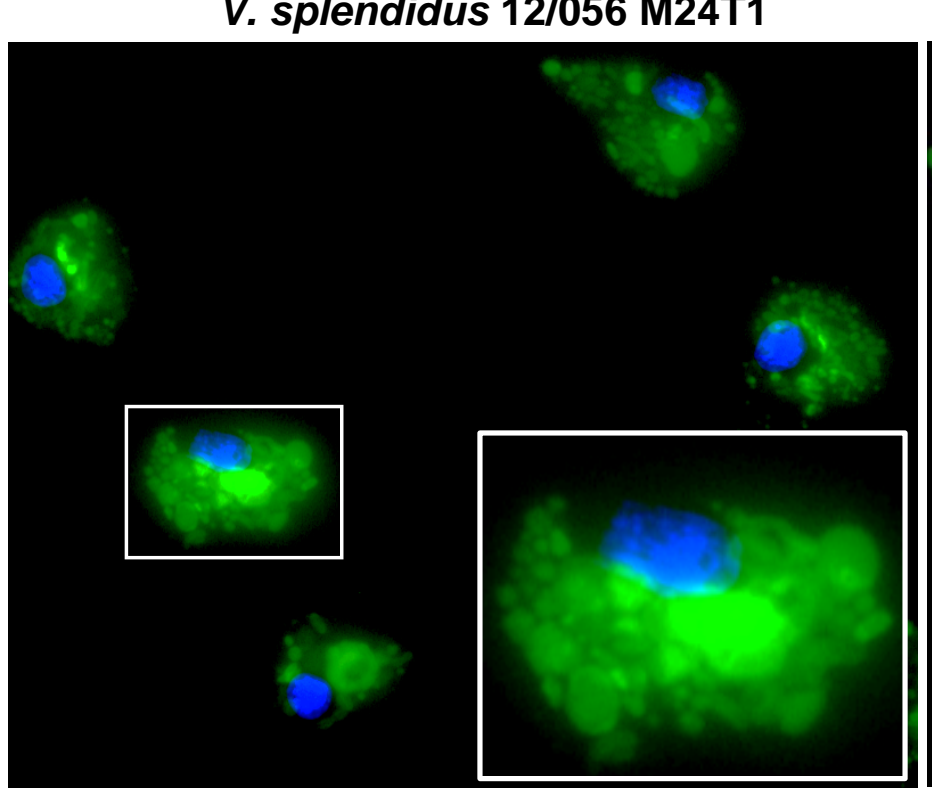

V. splendidus 10/068 1T1

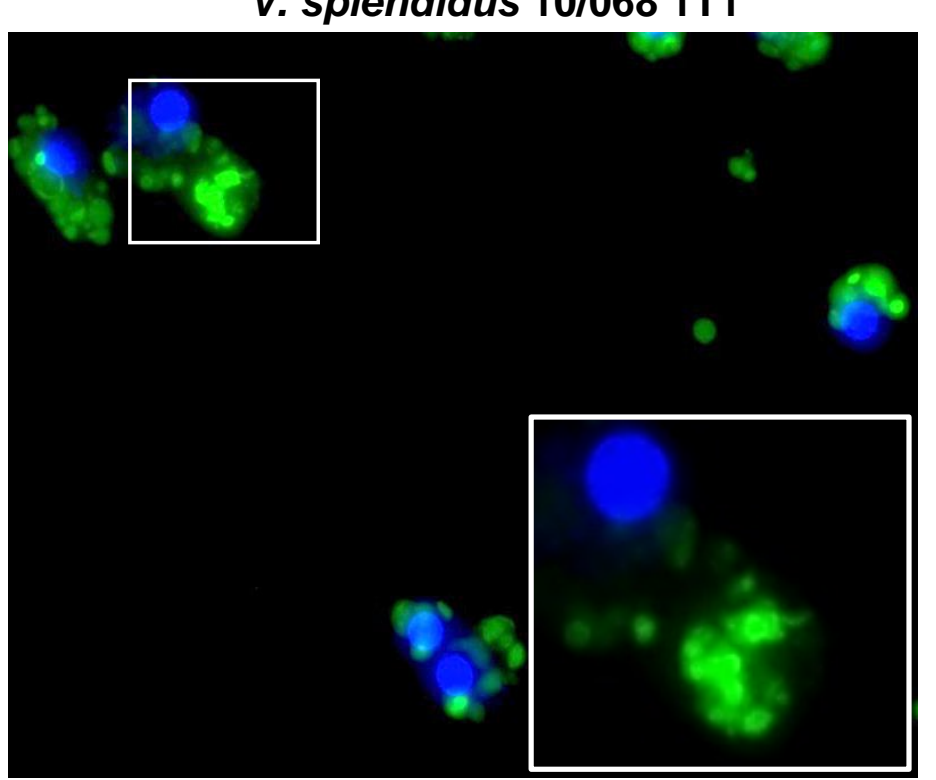


Figure 3

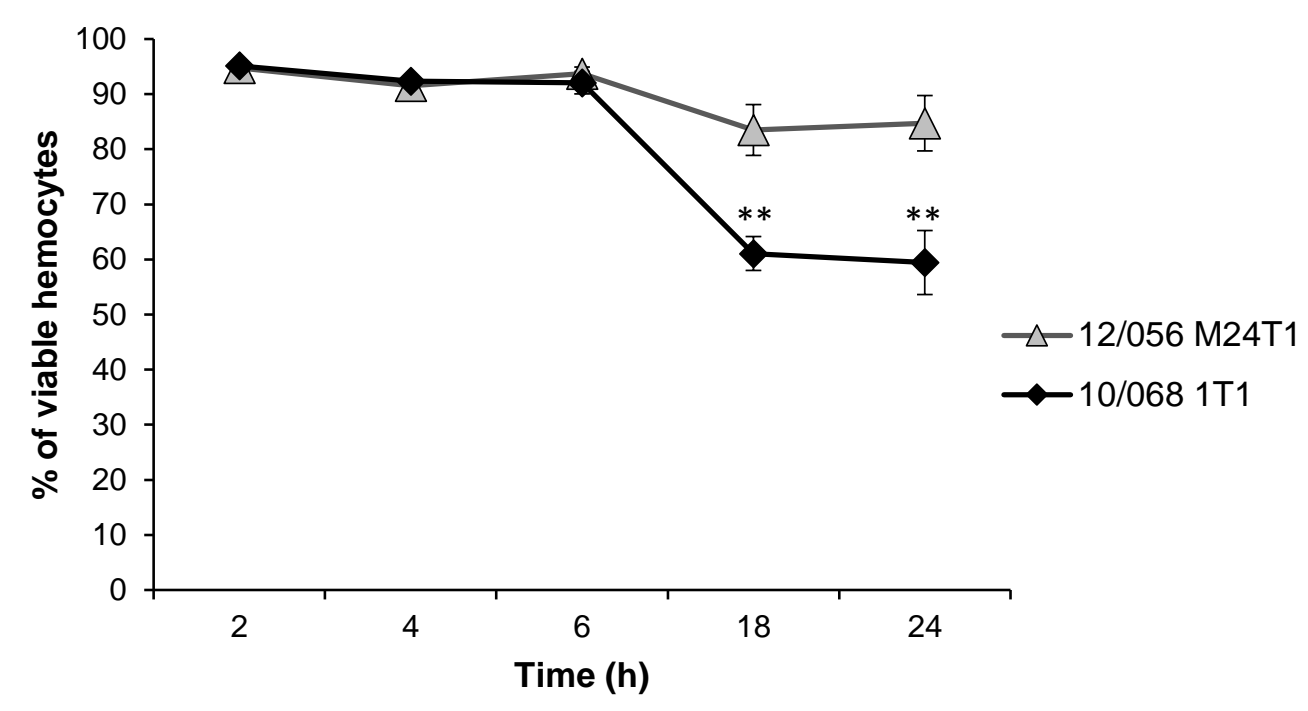


Figure 4

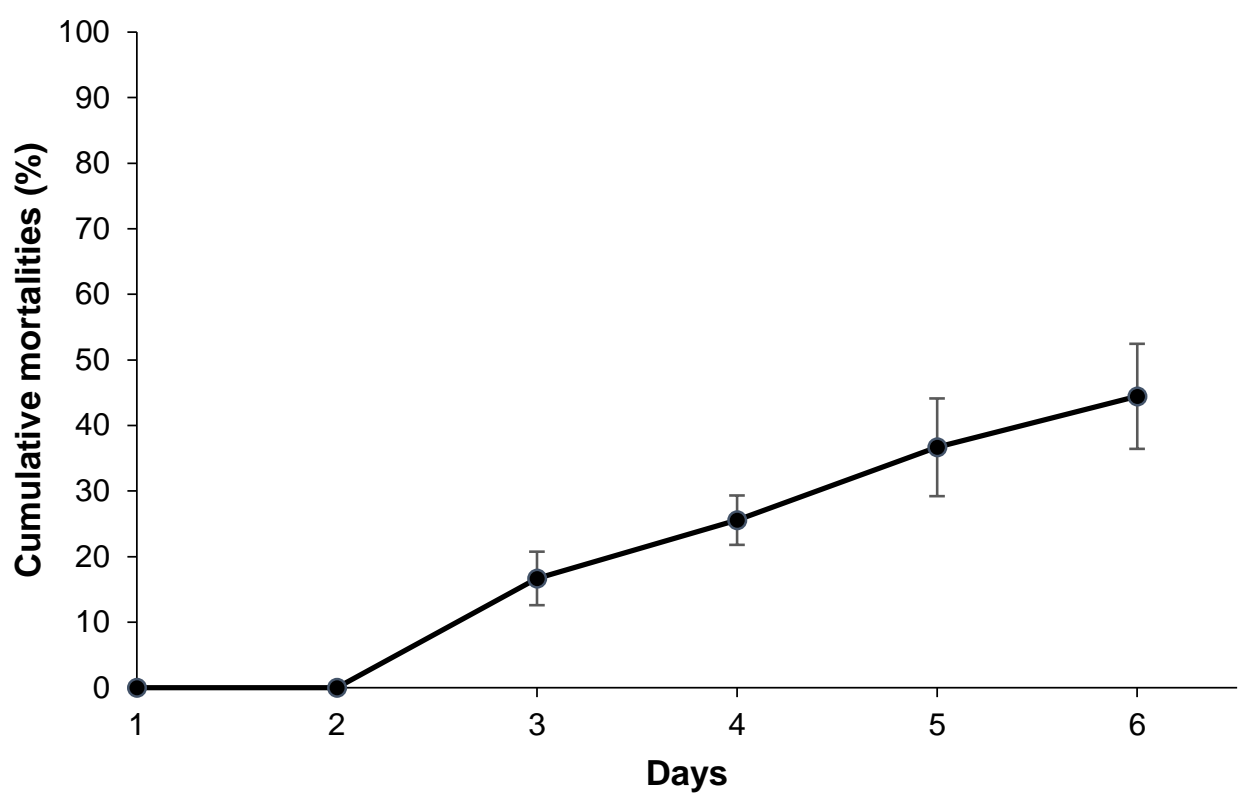


Figure 5

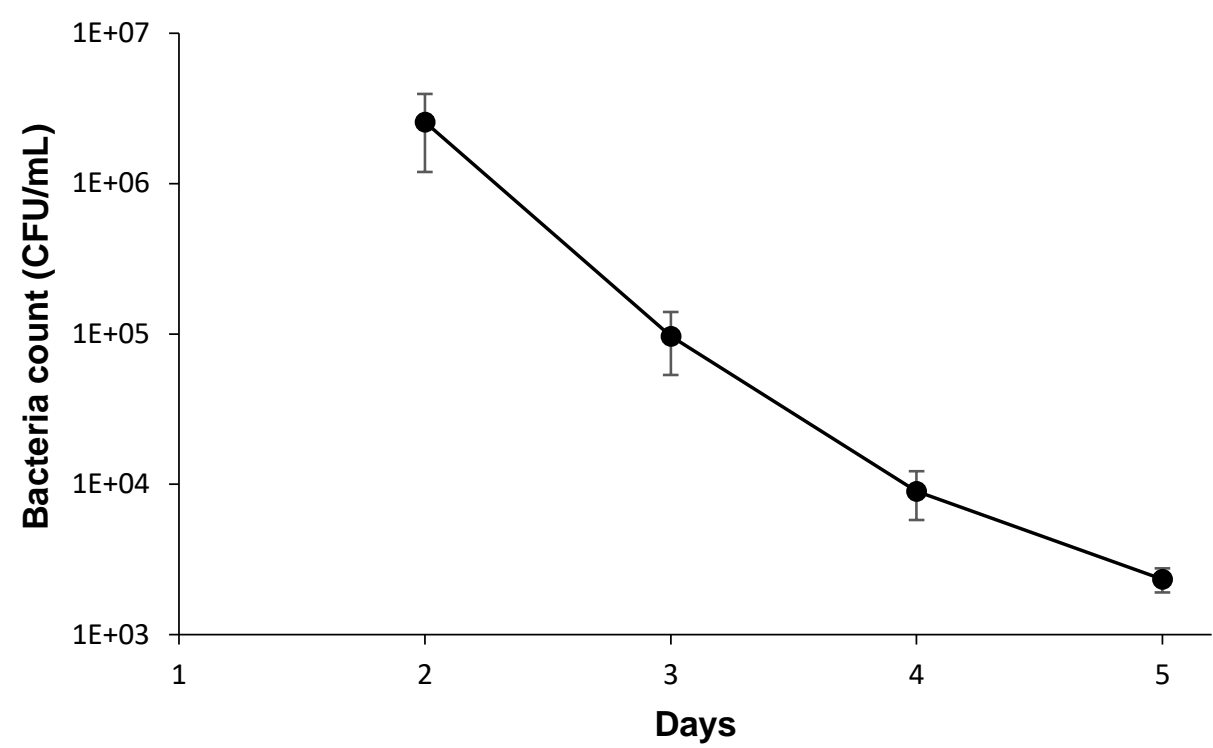


Figure 6

(a)

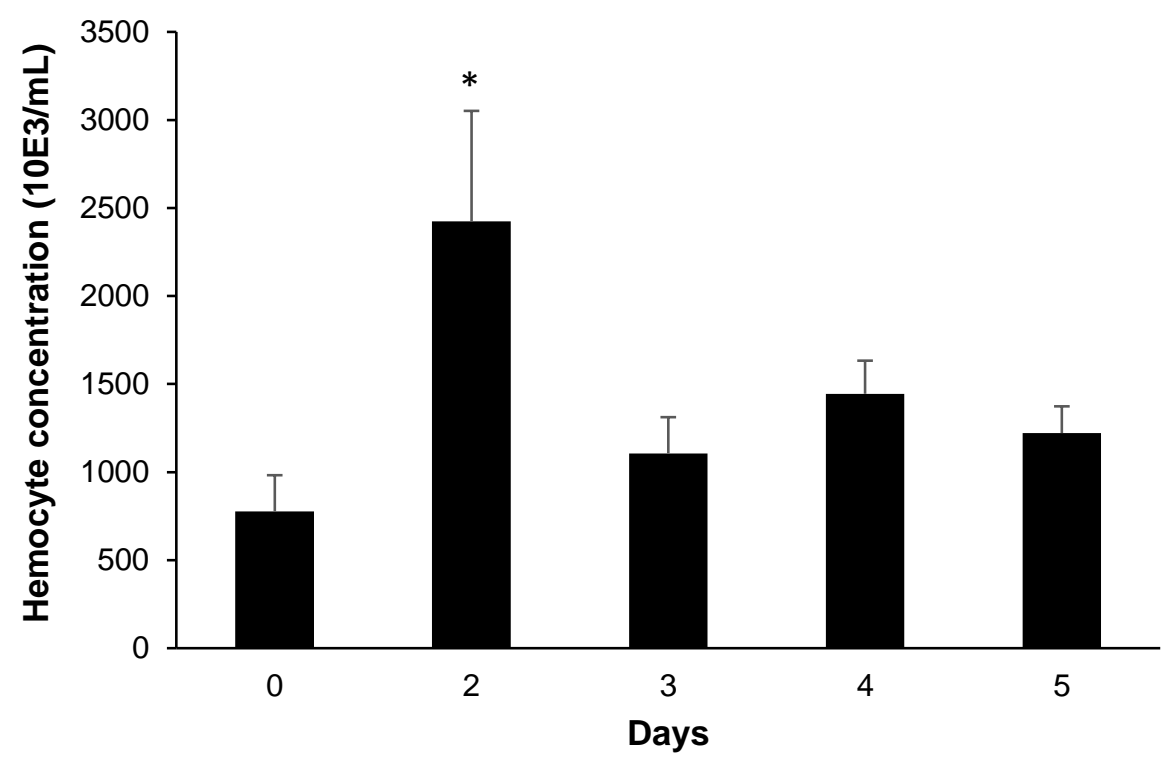

(b)

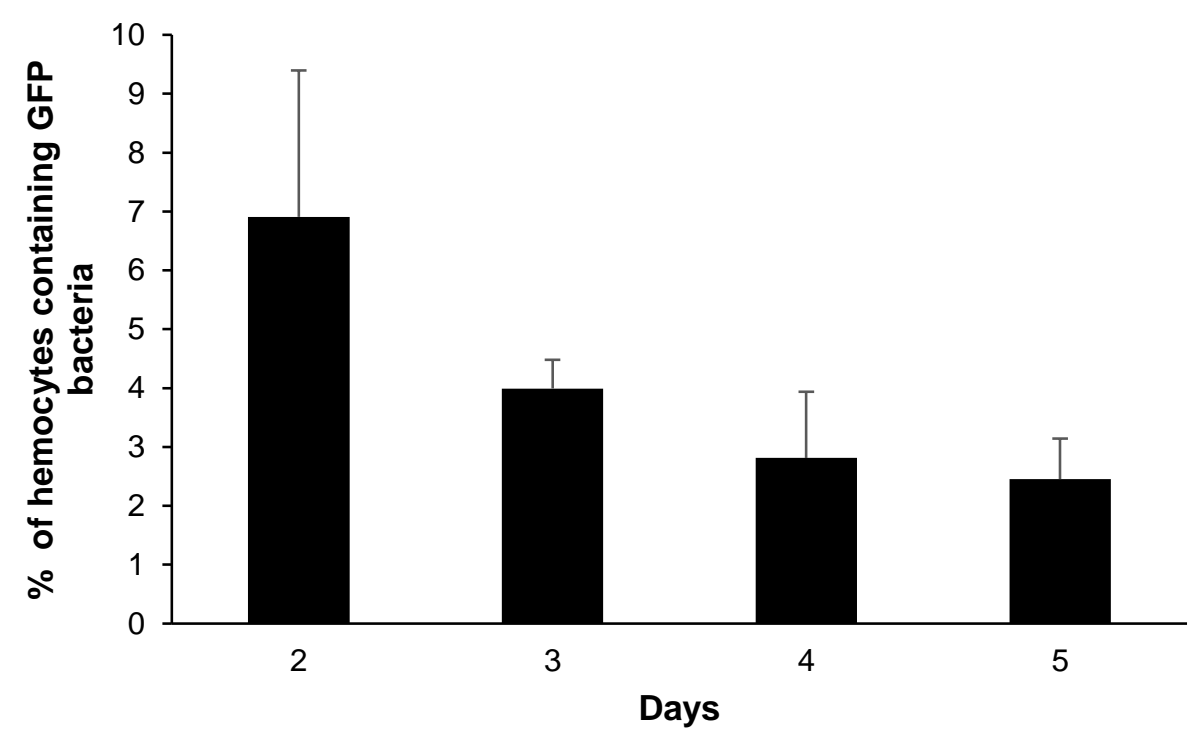

(c)

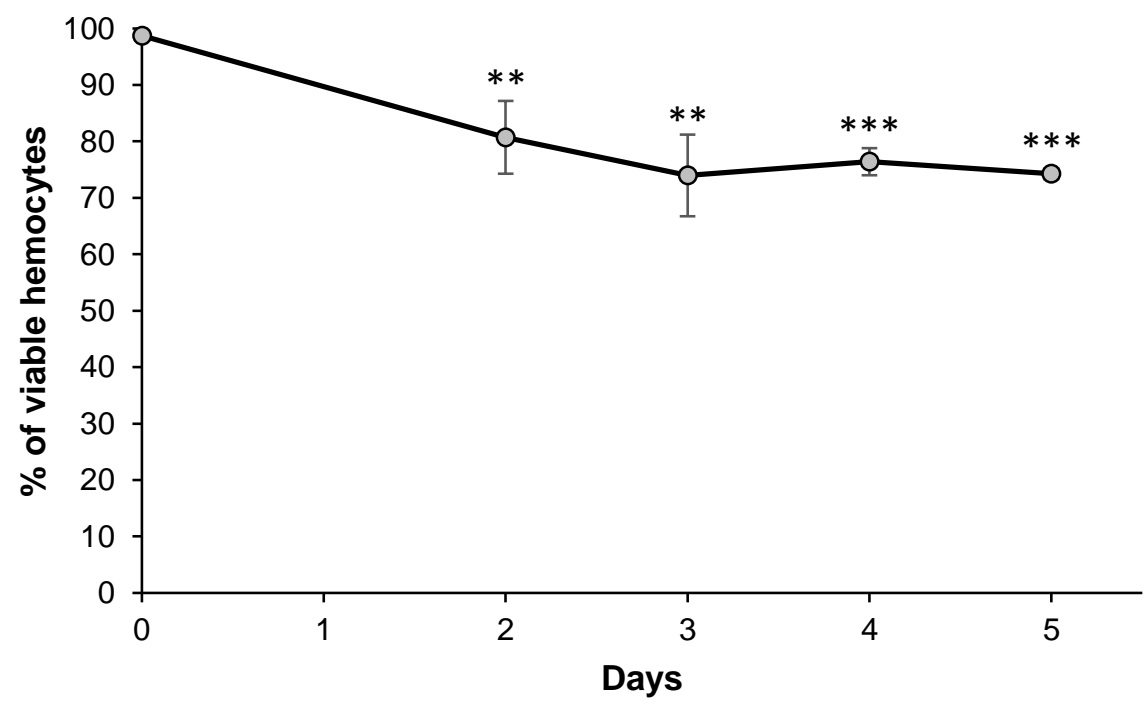


Figure 7
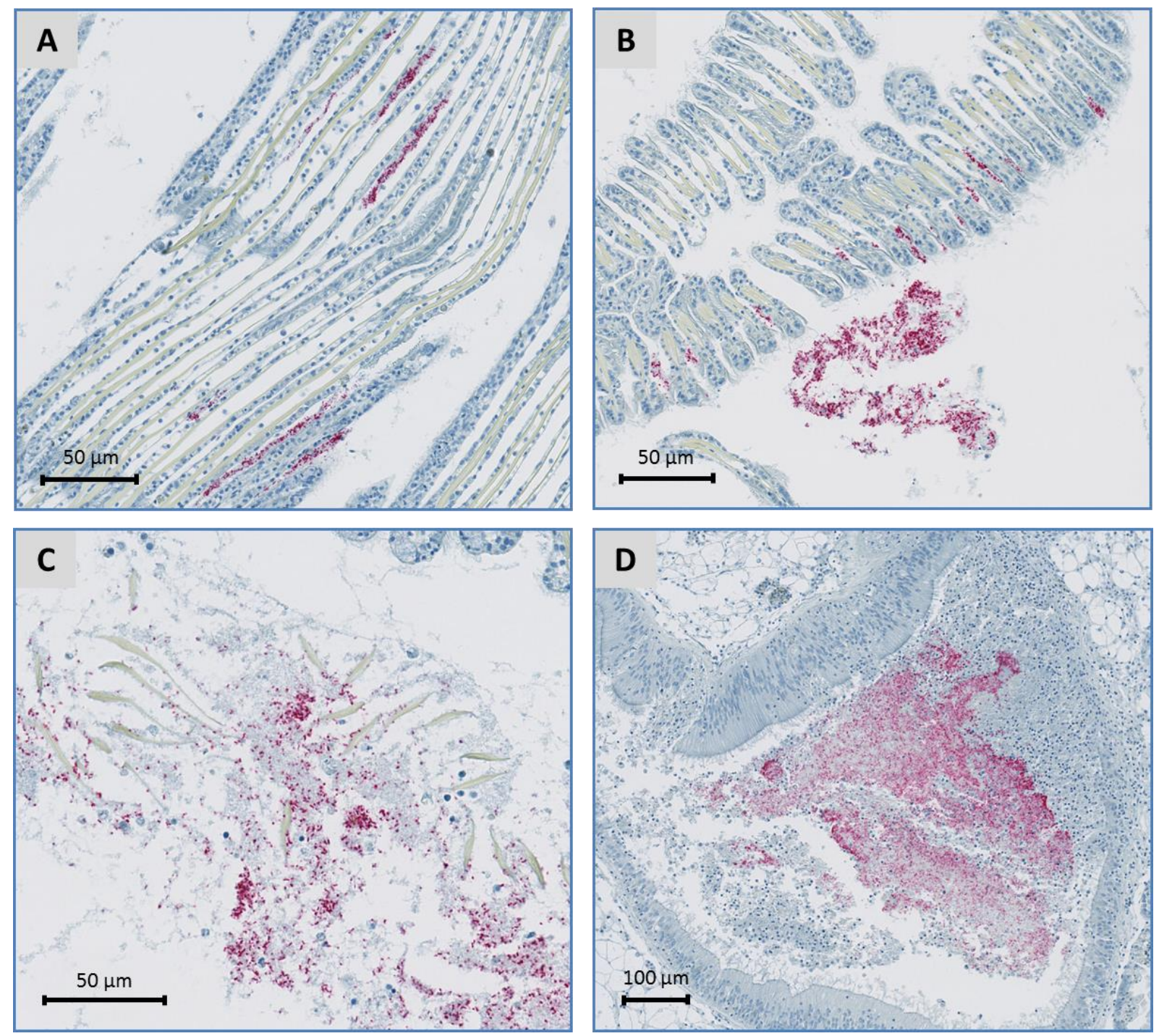
Supplementary figure 1
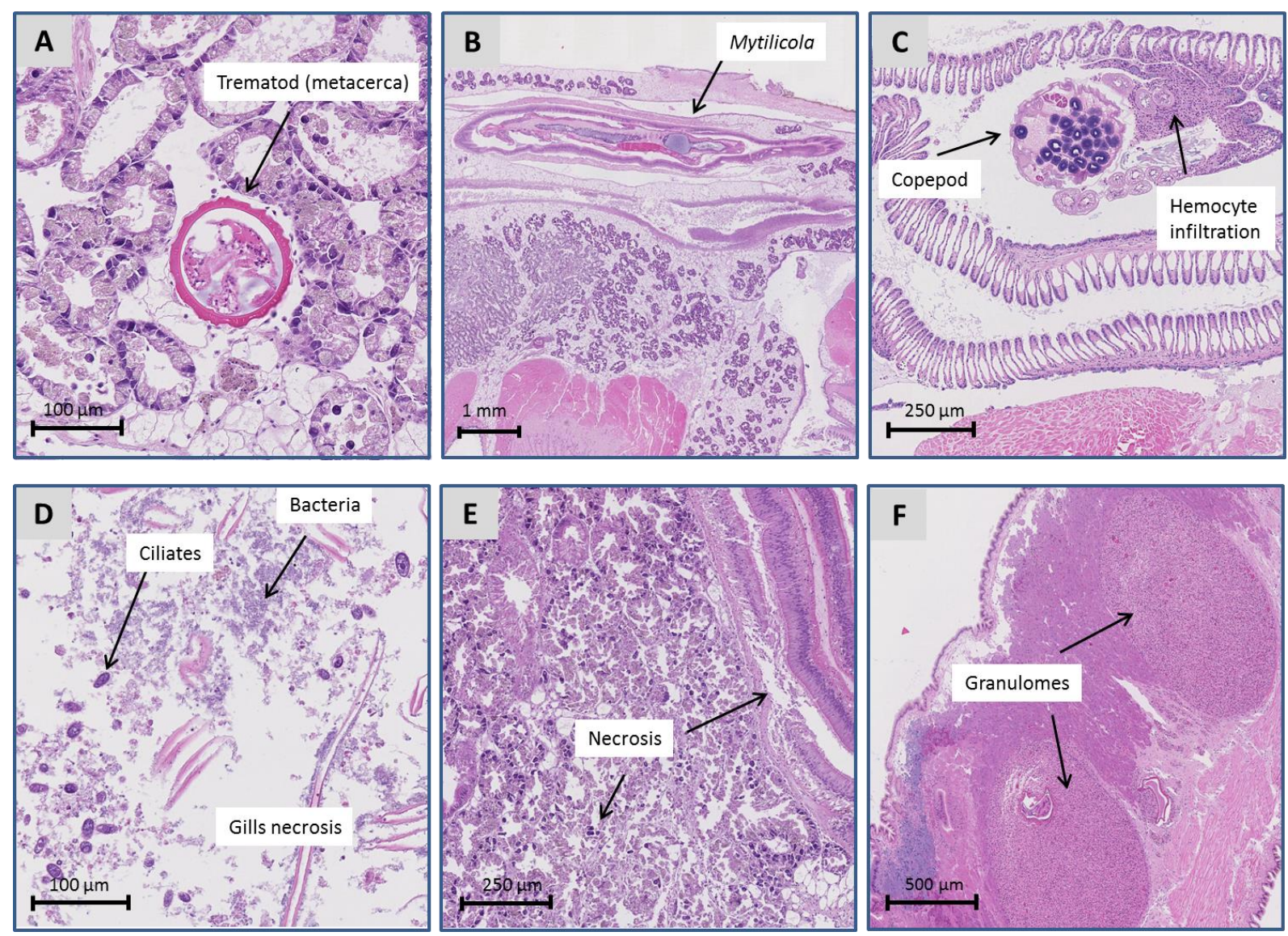